\title{
Biochar application affects forage sorghum under salinity stress
}

\author{
Muhi Eldeen Hussien Ibrahim ${ }^{1 *, 2}$, Adam Yousif Adam Ali ${ }^{1,3}$, Guisheng Zhou ${ }^{1}$, \\ Aboagla Mohammed Ibrahim Elsiddig ${ }^{1}$, Guanglong Zhu ${ }^{1}$, Nimir Eltyb Ahmed Nimir ${ }^{4}$, \\ and Irshad Ahmad ${ }^{1}$
}

${ }^{1}$ Yangzhou University, Joint International Research Laboratory of Agriculture and Agri-Product Safety of the Ministry of Education of China, Yangzhou 225009, China. "Corresponding author (mhsinada@yahoo.com).

${ }^{2}$ Sudan University of Science and Technology, College of Agricultural Studies, Khartoum 13311, Sudan.

${ }^{3}$ University of Gadarif, College of Agriculture and Environment Science, Gadarif 449, Sudan.

${ }^{4}$ University of Khartoum, Faculty of Agriculture, Khartoum 11115, Sudan.

Received: 5 November 2019; Accepted: 13 January 2020; doi:10.4067/S0718-58392020000300317

\begin{abstract}
Salinity is a growing problem worldwide and techniques are needed to mitigate this problem. The experiment was conducted to examine if biochar could improve growth, physiological response, and DM yield of forage sorghum (Sorghum bicolor (L.) Moench) under saline conditions. Sorghum seedlings were transplanted in sandy loam soil (0-20 cm layer of a Typic Fluvaquents Entisols) treated with sodium chloride at rates of $0.26,5.8$, and $12.6 \mathrm{dS} \mathrm{m}^{-1}$. The saline soil was treated with four biochar rates, $0 \%, 2.5 \%, 5 \%$, and $10 \%(\mathrm{w} / \mathrm{w})$. Plant height, fresh weight, photosynthetic rate (A), stomatal conductance $\left(\mathrm{g}_{\mathrm{s}}\right)$, transpiration rate $(\mathrm{E})$, catalase $(\mathrm{CAT})$, peroxidase (POD), and superoxide dismutase (SOD) were affected by the interaction between salinity and biochar. At the $12.6 \mathrm{dS} \mathrm{m}^{-1}$ salinity rate, $5 \%$ biochar increased plant height, leaf area, fresh weight, DM yields, $\mathrm{A}, \mathrm{g}_{\mathrm{s}}$, and $\mathrm{E}$ by $20.1 \%, 16.5 \%, 26.2 \%, 27.4 \%, 14.5 \%, 31.1 \%$, and $26.7 \%$, respectively. At the $12.6 \mathrm{dS} \mathrm{m}^{-1}$ salinity rate, 5\% biochar decreased CAT, POD, and SOD by 56.8\%, 44.8\%, and 18.9\%, respectively. Furthermore, among all biochar rates used in this investigation, the 5\% rate had a better result for forage sorghum production. These findings demonstrated that the lowest biochar soil amendment application could alleviate the harmful impact of salinity; a high biochar application rate can have a negative influence.
\end{abstract}

Key words: Forage yield, salinity, soil amendment, Sorghum bicolor.

\section{INTRODUCTION}

Saline soil is one of the important determining factors limiting crop production. The increasing global salinity problem is associated with irrigation that uses bad quality irrigation water and the transport of subsurface salts to the surface soil by capillary movement or drainage in dryland systems (Wassmann et al., 2009). Salt stress usually alters crop growth through the effect of chloride and $\mathrm{Na}$ ions on the plant by specific ion toxicity, which occurs when these components in the soil water are absorbed by the roots and accumulate in plant stems or leaves. High concentrations of $\mathrm{Na}$ and chloride are often synonymous of a high salinity level (Munns and Tester, 2008).

An emerging source of information shows that biochar application is valuable to increase the growth, physiological, and biochemical characteristics of the plant under saline conditions (Akhtar et al., 2015a; Amini et al., 2016). Some researchers have also observed increased soil salinity with high biochar levels. There is insufficient information about the long-term performance of saline soils treated with biochar (Thomas et al., 2013). 
The use of biochar has been useful in reducing the effect of salt stress by enhancing soil physicochemical and biological characteristics directly related to Na leaching, Na adsorption ratio, and electrical conductivity (EC) (Dahlawi et al., 2018). The overall mean increase in crop productivity due to increased plant growth and biomass with biochar amendment described in the literature is approximately $10 \%$ to $12 \%$ (Kim et al., 2016). Some studies have revealed an adverse impact on crop productivity when biochar was added to the soil; this can be due to specific types of biochar (Liu et al., 2013; Yu et al., 2019). The important factor or mechanism behind improving contaminated soil with biochar was its high adsorption capacity (She et al., 2018).

Salinity is known to generate oxidative stress in plants by the extreme production of reactive oxygen species (ROS). Many studies describe that increased superoxide dismutase (SOD), peroxidase (POD), and catalase (CAT) activity are nearly correlated to the salt tolerance of several crops (Talaat and Shawky, 2014; Ibrahim et al., 2018b). These conclusions suggest that the induction of ROS-scavenging enzymes, such as SOD, POD, and CAT, is the most popular salt sensitivity mechanism for ROS production (Gao et al., 2008). A byproduct of the SOD activity is the toxic species $\mathrm{H}_{2} \mathrm{O}_{2}$, which must be decreased to stop cellular damage by its reformation to $\mathrm{H}_{2} \mathrm{O}$; results include ascorbate peroxidase, POD, and CAT, which improve $\mathrm{H}_{2} \mathrm{O}_{2}$ levels in plants (Ibrahim et al., 2018b). An increase in antioxidant enzymes under salt stress might suggest increased ROS and improved protective mechanism to decrease oxidative damage triggered by stress in plants. Catalase in peroxisomes breaks down $\mathrm{H}_{2} \mathrm{O}_{2}$. Peroxidase in cytosol and chloroplast can correctly scavenge $\mathrm{H}_{2} \mathrm{O}_{2}$. An increase of POD activity by the salt treatment in plants has also been reported by Kahrizi et al. (2012). Organic amendments have mitigated salt stress in plants by improving antioxidant enzyme synthesis in plants (Tartoura et al., 2014). A few studies have described the impact of biochar on oxidative stress and antioxidant enzyme activity in plants grown under salt stress. For example, biochar application reduced ascorbate peroxidase (APX) activity in maize exposed to salinity compared with the control (Kim et al., 2016). Therefore, we hypothesized that the adverse impact of salt stress could be alleviated by biochar application. The aim of the present study was to explore the probability of alleviating salt stress on sorghum by applying biochar soil amendment.

\section{MATERIALS AND METHODS}

Sorghum (Sorghum bicolor (L.) Moench) 'Kambal', which was improved from the traditional 'Abu Sabien' line of the Variety Release Committee (VRC) in 2004, was obtained by the Agricultural Research Corporation, Sudan, for the present study. Seeds were soaked in $2.5 \% \mathrm{NaClO}$ solution for 3 to $7 \mathrm{~min}$ to sterilize them, washed three times with distilled water, and air-dried.

The soil was the 0-20 cm layer of a Typic Fluvaquents collected from the surface of sandy loam soil $(0-20 \mathrm{~cm})$ at the Experimental Farm of Yangzhou University $\left(32.30^{\circ} \mathrm{N}, 119.43^{\circ} \mathrm{E}\right)$, Jiangsu Province, China. The soil was dried and sieved with a $5 \mathrm{~mm}$ sieve. It was spread at an approximate thickness of $50 \mathrm{~mm}$ on a piece of polyethylene sheet. Soil and biochar suspensions were prepared in deionized water at a 1:2 soil:water ratio (Sonneveld and van den Ende, 1971). The suspension was moved and allowed to stand overnight. Electrical conductivity (EC 1:1) was measured with an EC meter (TZS-EC-I, Zhejiang Top Instrument Co. Ltd., Hangzhou, China). The soil and biochar samples were analyzed for pH (1:1 in water) with a pH meter (Benchtop pH-meter, U33100-1011690-pH meter, 3B Scientific GmbH, Hamburg, Germany). Soil organic $\mathrm{C}$ was determined according to the Walkley-Black chromic acid wet oxidation method (Nelson and Sommers, 1996), $\mathrm{N}$ by the Kjeldahl method described by Labconco (1998), available P by the micro-vanadate-molybdate method (Olsen, 1954), and available $\mathrm{K}$ by the neutral ammonium acetate extract method with a flame photometer (Chapman and Pratt, 1962). The physical and chemical properties of the soil and biochar used in this experiment are shown in Table 1.

The experiment was conducted at the Experimental Farm of Yangzhou University, Yangzhou, in the sorghum growing season (summer 2018). The sowing date was 10 July 2018. The study was conducted as a factorial experiment arranged in a randomized complete block design with three replicates. Treatments included four different biochar rates $(0 \%, 2.5 \%, 5 \%$, and $10 \% \mathrm{w} / \mathrm{w})$ designated as $\mathrm{BC} 0 \%, \mathrm{BC} 2.5 \%, \mathrm{BC} 5 \%$, and $\mathrm{BC} 10 \%$, respectively, and three salinity rates of $0.26,5.8$, and $12.6 \mathrm{dS} \mathrm{m}^{-1}$ designated as S0, S1, and S2, respectively. Saline soils were prepared by incorporating $\mathrm{NaCl}$. Wheat straw biochar was applied, which was pyrolyzed at $500{ }^{\circ} \mathrm{C}$ in a vertical oven made of refractory bricks from the Sanli New Energy Company, Henan Province, China. This technology extracted 30\% of wheat straw DM, which was transformed into biochar. Every pot $(32 \times 30 \mathrm{~cm})$ contained $10 \mathrm{~kg}$ dry soil. Four seedlings 
Table 1. Basic properties of the studied soil and biochar.

\begin{tabular}{|c|c|c|}
\hline Parameter & Soil & Biochar \\
\hline Electrical conductivity (EC1:1), $\mathrm{dS}^{-1}$ & 0.26 & 1.40 \\
\hline $\mathrm{pH}$ & 7.80 & 9.90 \\
\hline Organic matter, $\mathrm{g} \mathrm{kg}^{-1}$ & 1.22 & 398.40 \\
\hline Total $\mathrm{N}, \mathrm{g} \mathrm{kg}^{-1}$ & 1.00 & 7.43 \\
\hline Total $\mathrm{P}, \mathrm{g} \mathrm{kg}^{-1}$ & 14.10 & 10.70 \\
\hline Total $\mathrm{K}, \mathrm{g} \mathrm{kg}^{-1}$ & 0.77 & 13.60 \\
\hline Cation exchange capacity, $\mathrm{cmol} \mathrm{kg}^{-1}$ & 16.85 & 120.60 \\
\hline
\end{tabular}

( $7 \mathrm{~d}$ old) were transplanted. There were 12 treatments in the study with three replicates for each treatment. There were 36 pots, and all pots were placed in the open field. Plastic film was placed over the pots when rain was expected. Tap water $\left(\right.$ EC $0.4 \mathrm{dS} \mathrm{m}^{-1}$ ) was used. Pots were weighed every 2 or $3 \mathrm{~d}$ to maintain soil water content at $80 \%$ field capacity. The pots had no holes at the bottom to prevent drainage and leaching.

\section{Growth measurements}

The agronomic evaluations were done at the milky stage, and measurements were averaged. Growth parameters were analyzed based on plant measurements; three plants per pot were selected, plant height was measured from the base of the plant at the soil surface to the tip of the head, and mean plant height was calculated. Five leaves on the same plant were randomly selected from three plants per pot to measure leaf area with a leaf area meter (LI-3100C, LI-COR Biosciences, Lincoln, Nebraska, USA). Fresh weight was estimated from three plants per pot. For DM yield, plants were harvested 70 $\mathrm{d}$ after planting to determine $\mathrm{DM}$ yield $\left(\mathrm{t} \mathrm{ha}^{-1}\right)$ by oven-drying at $80^{\circ} \mathrm{C}$ for $2 \mathrm{~d}$ to constant weight.

\section{Plant physiological parameters}

Photosynthetic parameters included photosynthetic rate $\left(\mathrm{A}, \mu \mathrm{mol} \mathrm{CO} \mathrm{Cm}^{-2} \mathrm{~s}^{-1}\right)$, stomatal conductance $\left(\mathrm{g}_{\mathrm{s}}, \mathrm{mol} \mathrm{H}_{2} \mathrm{O} \mathrm{m}^{-2} \mathrm{~s}^{-1}\right)$, and transpiration rate $\left(\mathrm{E}, \mathrm{mmol} \mathrm{H}_{2} \mathrm{O} \mathrm{m}^{-2} \mathrm{~s}^{-1}\right)$; they were estimated with a portable photosynthesis system (LI-6400, LI-COR Biosciences, Lincoln, Nebraska, USA) from 07:30 to 10:30 h. Three leaves were chosen to determine the photosynthetic parameters.

The leaves of each treatment were sampled and immersed in liquid nitrogen for $15 \mathrm{~min}$ and then kept at $-75{ }^{\circ} \mathrm{C}$ to determine peroxidase (POD), catalase (CAT), and superoxide dismutase (SOD) activity. For enzyme extraction, frozen leaf samples of sorghum plant $(0.5 \mathrm{~g})$ were collected. Plant samples were ground into a fine powder in liquid nitrogen with mortar and pestle and then homogenized at $4{ }^{\circ} \mathrm{C}$ in $5 \mathrm{~mL}$ extraction buffer consisting of $50 \mathrm{mM}$ PBS, pH 7.8, 0.1 mM EDTA, $0.3 \%$ Triton X-100, 4\% polyvinylpolypyrrolidone (PVP), and centrifuged at $10500 \mathrm{rpm}$ and $4{ }^{\circ} \mathrm{C}$ for 20 $\mathrm{min}$; the supernatant was collected and placed on ice and used for antioxidant enzyme activity analysis. The POD activity was measured by the method described by Xu and Ye (1989). The SOD activity was determined according to Koca et al. (2007) and CAT activity according to Aebi (1984).

\section{Data analysis}

Data was analyzed according to the method by Gomez and Gomez, and the MSTAT-C statistical package (Freed et al., 1991) was used for ANOVA. When F values were significant, means were separated according to Tukey's range test (P $\leq 0.05$ ) by a protected ANOVA test.

\section{RESULTS}

Plant height was significantly affected by salinity, biochar, and the Salinity $\times$ Biochar interaction (Table 2). In the Salinity $\times$ Biochar interaction, the highest salinity rate $\left(12.6 \mathrm{dS} \mathrm{m}^{-1}\right)$ and $\mathrm{BC} 5 \%$ rate increased plant height by $20.1 \%$ compared with the control, while the BC 10\% treatment decreased plant height by $13.7 \%$ compared with the control (Figure 1A).

Leaf area was affected by salinity, and the Salinity $\times$ Biochar interaction (Table 2). At the $12.6 \mathrm{dS} \mathrm{m}^{-1}$ rate, the highest leaf area value was $272.1 \mathrm{~cm}^{2}$ recorded with $\mathrm{BC} 5 \%$. At the $12.6 \mathrm{dS} \mathrm{m}^{-1}$ rate, $\mathrm{BC} 5 \%$ increased leaf area by $16.5 \%$ compared with the control (Figure 1B). 
Table 2. Summary of ANOVA for effects of salinity (S), biochar (BC), and their interaction on plant height (PH), leaf area (LA), fresh weight (FW), dry matter yield (DMY), photosynthetic rate (A), stomatal conductance ( $\mathrm{g}_{\mathrm{s}}$ ), and transpiration rate $(E)$ of sorghum.

\begin{tabular}{lcccc}
\hline & Salinity $(\mathrm{S})$ & Biochar (BC) & $\mathrm{S} \times \mathrm{BC}$ & $\mathrm{CV} \%$ \\
\hline Plant growth parameters & & & & \\
PH & $*$ & $* *$ & $* *$ & 16.8 \\
LA & $*$ & $\mathrm{~ns}$ & $* *$ & 27.3 \\
FW & $\mathrm{ns}$ & $*$ & $* *$ & 24.9 \\
DMY & $\mathrm{ns}$ & $* *$ & $* *$ & 21.4 \\
\hline Plant physiological parameters & & & & \\
\hline A & $* *$ & $*$ & $*$ & 17.8 \\
gs & $*$ & $* *$ & $* *$ & 9.3 \\
E & $*$ & $* *$ & $* *$ & 17.0 \\
CAT & $\mathrm{ns}$ & $* *$ & $* *$ & 30.1 \\
POD & $* *$ & $* *$ & $* *$ & 33.6 \\
SOD & $* *$ & $* *$ & $* *$ & 17.6 \\
\hline
\end{tabular}

*Significant at $\mathrm{P} \leq 0.05$; **Significant at $\mathrm{P} \leq 0.01$; ns: nonsignificant.

CAT: Catalase; POD: peroxidase; SOD: superoxide dismutase.

Figure 1. Effects of the interaction between salinity (S) and biochar (BC) on plant height (A), leaf area (B), fresh weight (C), and dry matter yield (D) of sorghum.
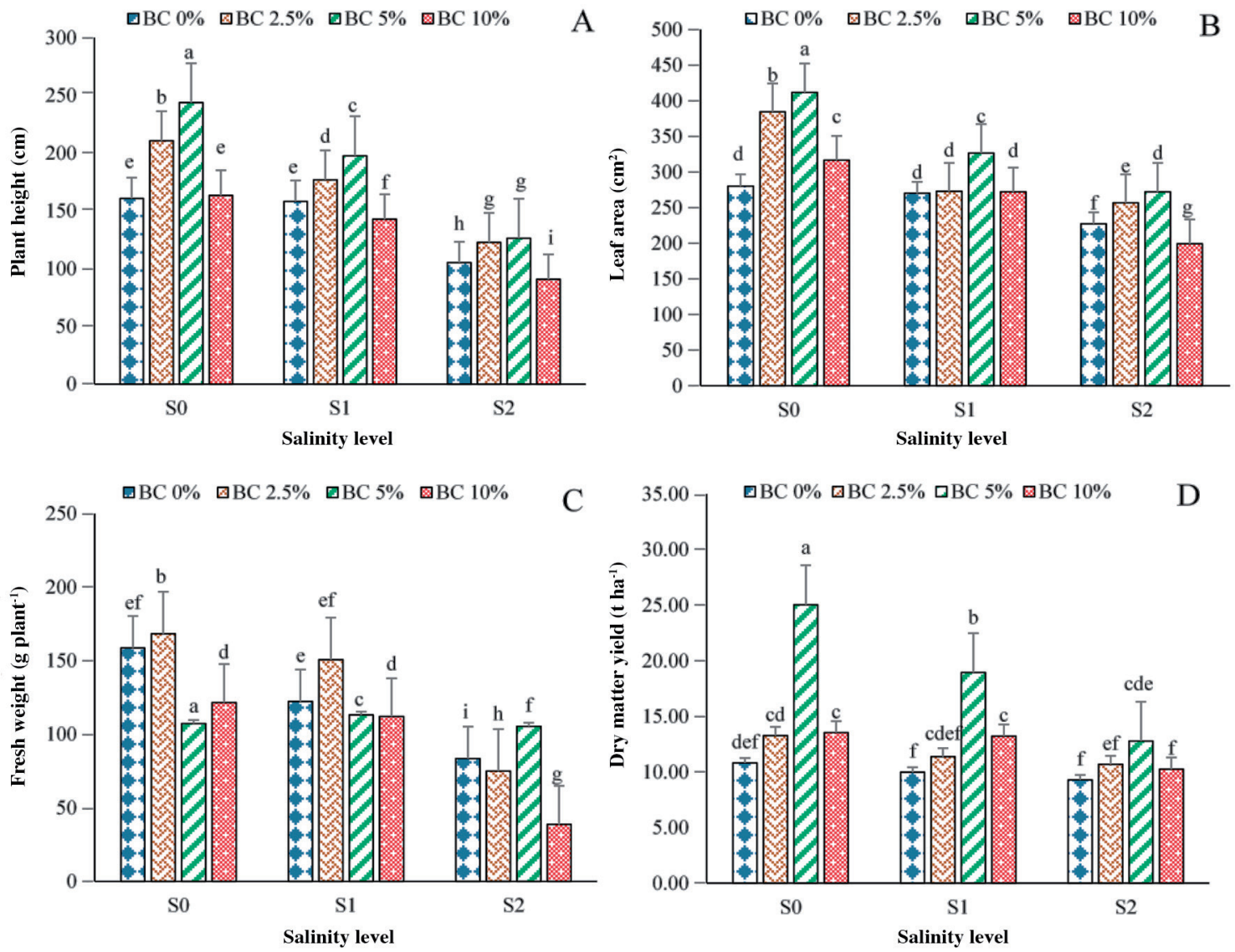

Bars with the same letter do not differ according to Tukey's range test $(\mathrm{P} \leq 0.05)$. S0, S1, and S2: $0.26,5.8$, and $12.6 \mathrm{dS} \mathrm{m}^{-1}$, respectively. 
Figure 2. Effects of the interaction between salinity (S) and biochar (BC) on photosynthetic rate (A), stomatal conductance (B), and transpiration rate (C) of sorghum.
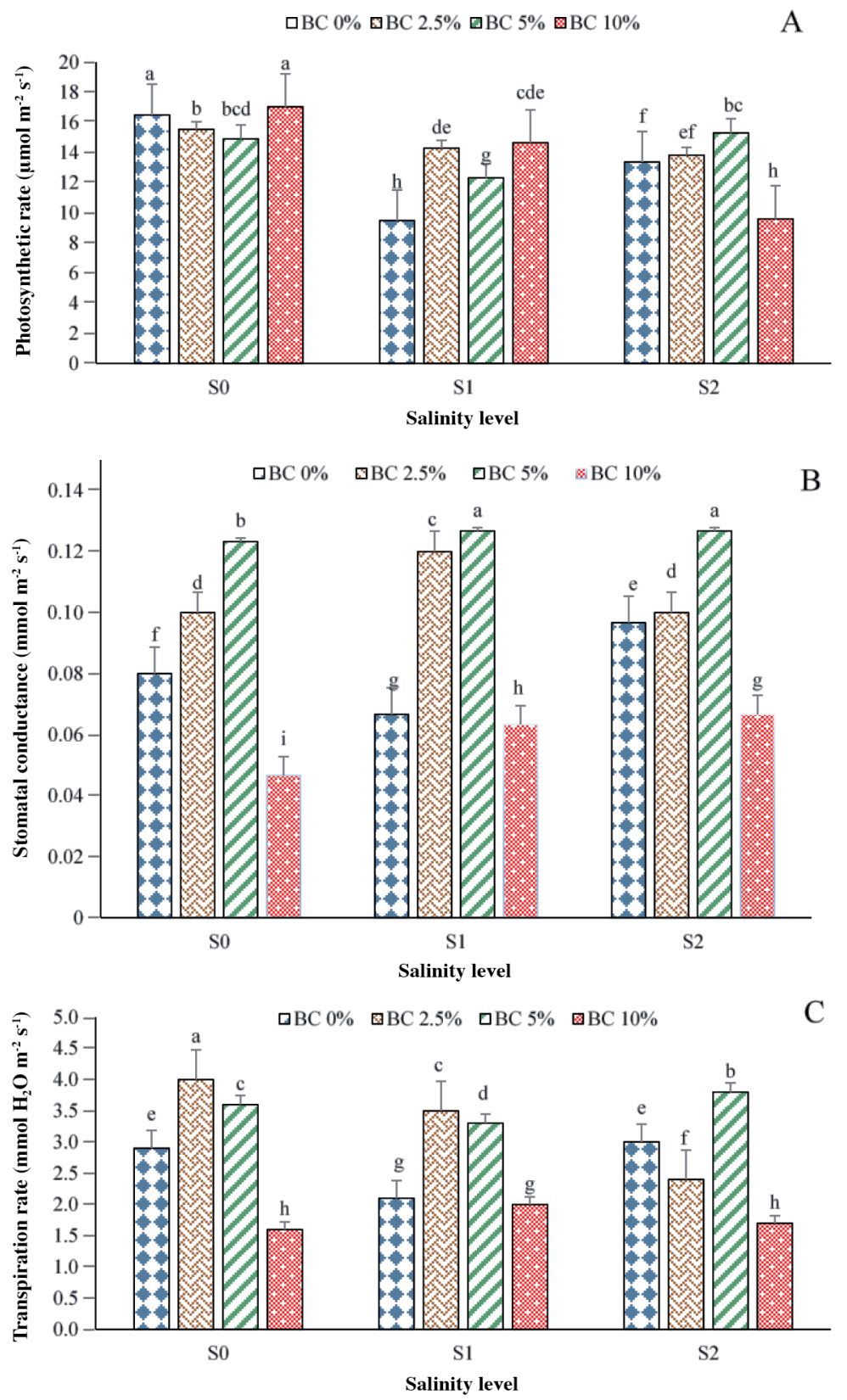

Bars with the same letter do not differ according to Tukey's range test $(\mathrm{P} \leq 0.05)$. $\mathrm{S} 0, \mathrm{~S} 1$, and S2: $0.26,5.8$, and $12.6 \mathrm{dS} \mathrm{m}^{-1}$, respectively.

Fresh weight was affected by biochar and the Salinity $\times$ Biochar interaction (Table 2). At the $12.6 \mathrm{dS} \mathrm{m}^{-1}$ rate, the highest fresh weight value was recorded with BC 5\% (105.4 $\left.\mathrm{g} \mathrm{plant}^{-1}\right)$ followed by BC $10 \%\left(83.5 \mathrm{~g} \mathrm{plant}^{-1}\right)$, BC $2.5 \%$ (74.9 $\left.\mathrm{g} \mathrm{plant}^{-1}\right)$, and BC 0\% (38.8 $\left.\mathrm{g} \mathrm{plant}^{-1}\right)($ Figure 1C).

Dry matter yield was affected by biochar and the Salinity $\times$ Biochar interaction (Table 2). At the $12.6 \mathrm{dS} \mathrm{m}^{-1}$ rate, the BC 5\% treatment increased DM yield by $27.41 \%$ compared with the control. Meanwhile, there was nonsignificant difference between the BC $0 \%$ and BC $10 \%$ treatments (Figure 1D). 
Parameters A, $\mathrm{g}_{s}$, and $\mathrm{E}$ were affected by salinity, biochar, and the Salinity $\times$ Biochar interaction (Table 2). At the 12.6 $\mathrm{dS} \mathrm{m}{ }^{-1}$ rate, the highest values of $\mathrm{A}$, $\mathrm{g}_{\mathrm{s}}$, and $\mathrm{E}$ were $15.31 \mu \mathrm{mol} \mathrm{CO} \mathrm{Cm}_{2} \mathrm{~m}^{-1}, 0.13 \mathrm{~mol} \mathrm{H}_{2} \mathrm{O} \mathrm{m}^{-2} \mathrm{~s}^{-1}$, and $3.8 \mathrm{mmol} \mathrm{H}_{2} \mathrm{O} \mathrm{m}^{-2} \mathrm{~s}^{-1}$, respectively, recorded with $\mathrm{BC} 5 \%$ (Figures $2 \mathrm{~A}, 2 \mathrm{~B}$, and $2 \mathrm{C}$ ).

The highest CAT activity occurred in plants exposed to salinity as compared with the control. At the highest salinity level, the BC 5\% application mitigated the increase of CAT activity, which decreased by $56.8 \%$ compared with the control (Figure 3A). At the highest salinity rate of $12.6 \mathrm{dS} \mathrm{m}^{-1}$, the BC $5 \%$ treatment decreased POD activity by $44.5 \%$ compared with the control (BC 0\%) (Figure 3B).

The results of SOD activity showed a highly significant difference among salinity rates. In the Salinity $\times$ Biochar interaction at the $12.6 \mathrm{dS} \mathrm{m}^{-1}$ salinity rate, BC $2.5 \%$ decreased SOD activity by $18.9 \%$ compared with BC $0 \%$ (Figure 3C).

Figure 3. Effects of the interaction between salinity (S) and biochar (BC) on the activity of catalase (CAT) (A), peroxidase (POD) (B), and superoxide dismutase (SOD) (C) of sorghum.
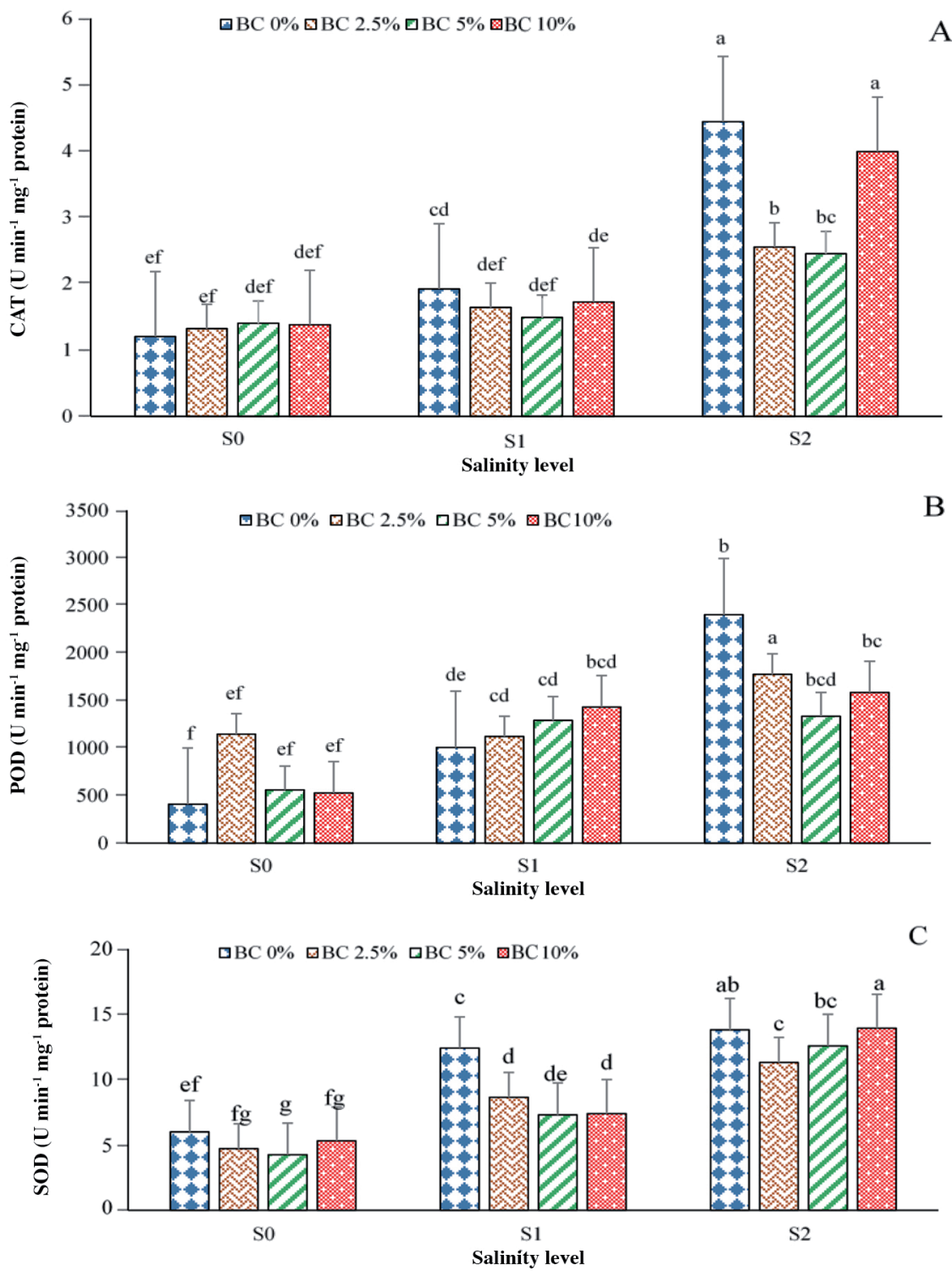

Bars with the same letter do not differ according to Tukey's range test $(\mathrm{P} \leq 0.05)$. S0, S1, and S2: 0.26, 5.8, and $12.6 \mathrm{dS} \mathrm{m}^{-1}$, respectively. 


\section{DISCUSSION}

Understanding the interactions between abiotic stresses and soil amendments has high economic value. Various studies have been conducted to determine the impact of biochar application to mitigate the damage caused by salt stress (She et al., 2018). Besides, the biochar result is also influenced by soil type (Liu et al., 2013).

The characteristics of biochar seem to be mainly responsible for most situations in which biochar works to alleviate the adverse impact of abiotic stress, both by decreasing plant exposure to stress or by enhancing plant stress resistance (Buss et al., 2012). It is probable that biochar alleviated the adverse impact of salinity in sorghum plants by three main mechanisms: reducing transient $\mathrm{N}^{+}$by adsorption, releasing mineral nutrients, and decreasing osmotic stress by improving soil water availability (Akhtar et al., 2015a). Novak et al. (2012) reported that biochar has strong absorptive properties; binding refers to its high porosity, surface area, and cation exchange capacity. By adsorbing toxic ions or releasing more beneficial ions, biochar can therefore decrease the adverse impact of salinity on plants either by decreasing plant exposure to stress agents or by alleviating plant stress responses (Novak et al., 2012; Akhtar et al., 2015b; 2015c).

Plant growth and physiological response disruptions caused by salinity have been widely studied (Ibrahim et al., 2016). Our study has explained that growth parameters were negatively affected by salt stress. These reductions in plant growth could be due to the harmful effect of salinity that occurs when inducing physical dehydration by osmotic impact that blocks water movement in the plants and by ion toxicity (Munns and Tester, 2008). These results concur with the studies by Ibrahim et al. (2018a; 2018b) and She et al. (2018). In the present study, there was a significant reduction in $\mathrm{A}, \mathrm{E}$, and $\mathrm{g}_{\mathrm{s}}$ caused by salt stress with the maximum decrease at the highest salinity rate.

Moreover, growth parameters, $\mathrm{A}, \mathrm{g}_{\mathrm{s}}$, and $\mathrm{E}$ were positively affected by biochar treatments, which suggested that biochar could alleviate the adverse impact of salinity stress on plants. The positive effect of biochar on growth and physiological responses agrees with results reported by She et al. (2018). Biochar application in saline soils is reported as enhancing plant growth, biomass, and photosynthesis. For example, biochar improved shoot biomass, root length, and yield in potatoes grown under salinity stress (Akhtar et al., 2015a). Rice hull biochar enhanced growth and biomass of maize exposed to salt stress (Kim et al., 2016). In another study, biochar application increased tomato growth and biomass under salinity stress when compared with the control (She et al., 2018). Thomas et al. (2013) examined the impact of biochar on the growth and biomass of two herbaceous species, Abutilon theophrasti and Prunella vulgaris, exposed to salinity stress, and the biomass of both plant species increased compared with the control. However, biochar did not significantly influence the photosynthetic parameters in both species under salt stress. Overall, the biochar response under salt stress differed with the plant species. Increased growth and biomass in soils treated with biochar application was previously mentioned (Thomas et al., 2013; Akhtar et al., 2015a; Zhu et al., 2018). Biochar application can improve plant growth and biomass under saline conditions (Akhtar et al., 2015a; 2015b).

It can be determined that photosynthetic parameters lead to plant growth stimulation observed on amended soil. These findings have revealed that biochar is a stable organic amendment and has an impact on mitigating salinity in sorghum. Some studies have concluded that biochar improved plant growth under salinity conditions (She et al., 2018). Plant growth in amended soil with biochar greatly reduces water waste through stomatal closure and transpiration, which preserves the water balance and leaf turgidity when plants are grown in saline soil (Akhtar et al., 2015a). In soil treated with $10 \%(\mathrm{w} / \mathrm{w})$ biochar, photosynthetic and growth parameters decreased in plants grown with a high salinity rate. The positive impact of biochar in plants grown under saline conditions is usually associated with an increase in $\mathrm{A}, \mathrm{g}_{\mathrm{s}}$, and $\mathrm{E}$. Several studies have shown that adding biochar to saline soils improved photosynthetic parameters (Thomas et al., 2013; Akhtar et al., 2015a).

The damaging impact of salt stress on plants can be recognized at all plant growth stages resulting in plant death and reduced production. High salinity affects plant growth by changing physiological processes (Muscolo et al., 2003). Plants have developed an antioxidant defense system to cope with oxidative damage under salinity stress (Foyer and Noctor, 2005). In the present study, results indicated that salinity stress increased CAT, POD, and SOD activity compared with non-saline conditions. This increase in antioxidant enzymes could be due to the activation of plant resistance mechanisms (Wang et al., 2016). Biochar application can regulate the synthesis of antioxidant enzymes in plants, and therefore improve salt stress in plants (Thomas et al., 2013). A few studies have shown the effect of biochar on oxidative stress and antioxidant enzyme activity in plants that grow under salinity stress. Under salt stress, biochar could improve plant growth 
by reducing oxidative stress. According to the results of previous research, biochar application decreased antioxidant enzyme activity in maize under salt stress (Kim et al., 2016). At the highest salinity levels, lower CAT and POD activity occurred in the 5\% biochar treatment, and lower SOD activity was recorded in the $2.5 \%$ biochar treatment. However, the highest biochar application level (10\%) revealed nonsignificant impact on antioxidant enzyme activities compared with the control. These findings demonstrated that the lowest biochar soil amendment application could alleviate the harmful effects of salinity on antioxidant enzymes, and the highest biochar application rate can have a negative influence as increased antioxidant enzymes. The negative impact of biochar on growth concurs with Huang et al. (2019), who reported that the yield increase under a high biochar amendment rate $\left(30 \mathrm{t} \mathrm{ha}^{-1}\right)$ was smaller, mainly due to high salinity and $\mathrm{N}$ immobilization. Biochar had a significant residual effect on alleviating adverse effects of salinity. For example, a study by Akhtar et al. (2015b) showed that biochar application reduced plant $\mathrm{Na}$ uptake by transient $\mathrm{Na}^{+}$binding due to its high adsorption capacity, decreasing osmotic stress by enhancing soil moisture content, and releasing mineral nutrients into the soil solution.

\section{CONCLUSIONS}

Biochar application improved the forage sorghum DM yield and increased physiological responses in plants. Overall, this study could provide a better understanding of the effect of biochar in plants under salinity stress. The application of biochar to these soils can reduce erosion and increase the yield potential of these soils. Nevertheless, further research is required to investigate the impact of biochar from different sources in more species under environmental conditions, including salinity stress.

\section{ACKNOWLEDGEMENTS}

This study was supported in part by the National Key R \& D Program of China (2018YFE0108100), Jiangsu Provincial Key R\&D Program (BE2016345), Jiangsu Provincial Agricultural Innovation Fund [CX16(1005)], the Priority Academic Program Development of Jiangsu Higher Education Institution, and the Natural Science Foundation of Jiangsu Higher Education Institutions of China (no. 17KJB210008).

\section{REFERENCES}

Aebi, H. 1984. Catalase in vitro. Methods in Enzymology 105:121-126.

Akhtar, S.S., Andersen, M.N., and Liu, F. 2015a. Biochar mitigates salinity stress in potato. Journal of Agronomy and Crop Science 201:368-378.

Akhtar, S.S., Andersen, M.N., and Liu, F. 2015b. Residual effects of biochar on improving growth, physiology and yield of wheat under salt stress. Agricultural Water Management 158:61-68.

Akhtar, S.S., Andersen, M.N., Naveed, M., Zahir, Z.A., and Liu, F. 2015c. Interactive effect of biochar and plant growthpromoting bacterial endophytes on ameliorating salinity stress in maize. Functional Plant Biology 42:770-781.

Amini, S., Ghadiri, H., Chen, C., and Marschner, P. 2016. Salt-affected soils, reclamation, carbon dynamics, and biochar: a review. Journal of Soils and Sediments 16:939-953.

Buss, W., Kammann, C., and Koyro, H.-W. 2012. Biochar reduces copper toxicity in Chenopodium quinoa Willd. in a sandy soil. Journal of Environmental Quality 41:1157-1165.

Chapman, H.D., and Pratt, P.F. 1962. Methods of analysis for soils, plants and waters. Soil Science 93:68.

Dahlawi, S., Naeem, A., Rengel,Z., and Naidu, R. 2018. Biochar application for the remediation of salt-affected soils: Challenges and opportunities. Science of the Total Environment 625:320-335.

Foyer, C.H., and Noctor, G. 2005. Oxidant and antioxidant signalling in plants: a re-evaluation of the concept of oxidative stress in a physiological context. Plant, Cell \& Environment 28:1056-1071.

Freed, R., Eisensmith, S., Everson, E., Weber, M., Paul, E., and Isleib, E. 1991. MSTAT-C: A Microcomputer Program for the design, management, and analysis of agronomic research experiments. Michigan State University, East Lansing, Michigan, USA.

Gao, S., Ouyang, C., Wang, S., Xu, Y., Tang, L., and Chen, F. 2008. Effects of salt stress on growth, antioxidant enzyme and phenylalanine ammonia-lyase activities in Jatropha curcas L. seedlings. Plant, Soil and Environment 54:374-381.

Huang, M., Zhang, Z., Zhai, Y., Lu, P., and Zhu, C. 2019. Effect of straw biochar on soil properties and wheat production under saline water irrigation. Agronomy 9:457. 
Ibrahim, M.E.H., Zhu, X., Zhou, G., Ali, A.Y.A., Ahmad, I., and Elsiddig, A.M.I. 2018a. Nitrogen fertilizer reduces the impact of sodium chloride on wheat yield. Agronomy Journal 110:1731-1737.

Ibrahim, M.E.H., Zhu, X., Zhou, G., Ali, A.Y.A., Ahmad, I., and Farah, G.A. 2018b. Nitrogen fertilizer alleviated negative impacts of $\mathrm{NaCl}$ on some physiological parameters of wheat. Pakistan Journal of Botany 50:2097-2104.

Ibrahim, M.E.H., Zhu, X., Zhou, G., Nimir, A., and Eltyb, N. 2016. Comparison of germination and seedling characteristics of wheat varieties from China and Sudan under salt stress. Agronomy Journal 108:85-92.

Kahrizi, S., Sedighi, M., and Sofalian, O. 2012. Effect of salt stress on proline and activity of antioxidant enzymes in ten durum wheat cultivars. Annals of Biological Research 3:3870-3874.

Kim, H.-S., Kim, K.-R., Yang, J.E., Ok, Y.S., Owens, G., Nehls, T., et al. 2016. Effect of biochar on reclaimed tidal land soil properties and maize (Zea mays L.) response. Chemosphere 142:153-159.

Koca, H., Bor, M., Özdemir, F., and Türkan, I. 2007. The effect of salt stress on lipid peroxidation, antioxidative enzymes and proline content of sesame cultivars. Environmental and Experimental Botany 60:344-351.

Labconco. 1998. A guide to Kjeldahl nitrogen determination methods and apparatus. Labconco Corporation, Kansas, Missouri, USA.

Liu, X., Zhang, A., Ji, C., Joseph, S., Bian, R., Li, L., et al. 2013. Biochar's effect on crop productivity and the dependence on experimental conditions - a meta-analysis of literature data. Plant and Soil 373:583-594.

Munns, R., and Tester, M. 2008. Mechanisms of salinity tolerance. Annual Review of Plant Biology 59:651-681.

Muscolo, A., Panuccio, M.R., and Sidari, M. 2003. Effects of salinity on growth, carbohydrate metabolism and nutritive properties of kikuyu grass (Pennisetum clandestinum Hochst). Plant Science 164:1103-1110.

Nelson, D.W., and Sommers, L.E. 1996. Total carbon, organic carbon, and organic matter. p. 961-1010. Sparks, D.L., Page, A.L., Helmke, P.A., Loeppert, R.H., Soltanpour, P.N., Tabatabai, M.A., et al. (eds.) Methods of Soil Analysis. Part 3. Chemical Methods. SSSA Book Series, Madison, Wisconsin, USA.

Novak, J.M., Busscher, W.J., Watts, D.W., Amonette, J.E., Ippolito, J.A., Lima, I.M., et al. 2012. Biochars impact on soilmoisture storage in an Ultisol and two Aridisols. Soil Science 177:310-320.

Olsen, S.R. 1954. Estimation of available phosphorus in soils by extraction with sodium bicarbonate. USA Department of Agriculture, Washington D.C., USA.

She, D., Sun, X., Gamareldawla, A.H., Nazar, E.A., Hu, W., and Edith, K. 2018. Benefits of soil biochar amendments to tomato growth under saline water irrigation. Scientific Reports 8:14743.

Sonneveld, C., and van den Ende, J. 1971. Soil analysis by means of a 1:2 volume extract. Plant and Soil 35:505-516.

Talaat, N.B., and Shawky, B.T. 2014. Modulation of the ROS-scavenging system in salt-stressed wheat plants inoculated with arbuscular mycorrhizal fungi. Journal of Plant Nutrition and Soil Science 177:199-207.

Tartoura, K.A., Youssef, S.A., and Tartoura, E.-S.A. 2014. Compost alleviates the negative effects of salinity via up-regulation of antioxidants in Solanum lycopersicum L. plants. Plant Growth Regulation 74:299-310.

Thomas, S.C., Frye, S., Gale, N., Garmon, M., Launchbury, R., Machado, N., et al. 2013. Biochar mitigates negative effects of salt additions on two herbaceous plant species. Journal of Environmental Management 129:62-68.

Wang, J., Guo, C., Dai, Q., Feng, B., Zuo, K., and Lin, M. 2016. Salt tolerance conferred by expression of a global regulator IrrE from Deinococcus radiodurans in oilseed rape. Molecular Breeding 36:88.

Wassmann, R., Jagadish, S., Heuer, S., Ismail, A., Redona, E., Serraj, R., et al. 2009. Climate change affecting rice production: the physiological and agronomic basis for possible adaptation strategies. Advances in Agronomy 101:59-122.

$\mathrm{Xu}$, L., and Ye, M. 1989. A measurement of peroxidase activity using continuous recording method. Journal of Nanjing Agricultural University 12:82-83.

Yu, H., Zou, W., Chen, J., Chen, H., Yu, Z., Huang, J., et al. 2019. Biochar amendment improves crop production in problem soils: A review. Journal of Environmental Management 232:8-21.

Zhu, Q., Kong, L., Xie, F., Zhang, H., Wang, H., and Ao, X. 2018. Effects of biochar on seedling root growth of soybeans. Chilean Journal of Agricultural Research 78:549-558. doi:10.4067/S0718-58392018000400549. 